\title{
A geophilomorph centipede (Chilopoda) from La Buzinie amber (Late Cretaceous, Cenomanian), SW France
}

\author{
Gregory D. EDGECOMBE \\ Natural History Museum, Department of Palaeontology, \\ Cromwell road, London SW7 5BD (United Kingdom) \\ g.edgecombe@nhm.ac.uk
}

Alessandro MINELLI

Lucio BONATO

Università degli Studi di Padova, Dipartimento di Biologia, via Ugo Bassi 58 B, I-35131 Padova (Italy)

alessandro.minelli@unipd.it

lucio.bonato@unipd.it

KEY WORDS

Chilopoda,

Geophilomorpha,

Schendylidae,

Geophilidae,

Buziniphilus n. gen., amber,

Cretaceous,

France,

new genus,

new species.
Edgecombe G. D., Minelli A. \& Bonato L. 2009. - A geophilomorph centipede (Chilopoda) from La Buzinie amber (Late Cretaceous, Cenomanian), SW France. Geodiversitas 31 (1): 29-39.

\section{ABSTRACT}

The first geophilomorph centipede to be documented from Mesozoic amber and the second Mesozoic member of the order is described as Buziniphilus antiquus n. gen., n. sp. It is represented by a single, probably immature specimen from Early Cenomanian amber at La Buzinie, Champniers, Charentes, France. Buziniphilus n. gen. is most probably a member of either Schendylidae or Geophilidae, though documentation of the labrum and mandibles is required to make a definitive familial assignment. Referral of Buziniphilus $\mathrm{n}$. gen. to the crown-group Adesmata, together with a reinterpretation of the structure of the forcipulae in the Jurassic Eogeophilus Schweigert \& Dietl, 1997, reinforces the modern aspect of Mesozoic chilopods that had been indicated by Cretaceous scutigeromorph and scolopendromorph fossils. 


\section{MOTS CLÉS \\ Chilopoda, \\ Geophilomorpha, \\ Schendylidae, \\ Geophilidae, \\ Buziniphilus n. gen., ambre, \\ Crétacé, \\ France, \\ genre nouveau, \\ espèce nouvelle.}

\section{RÉSUMÉ}

Un chilopode géophilomorphe (Chilopoda) de l'ambre de La Buzinie (Crétacé supérieur, Cénomanien), SW de la France.

Le premier chilopode géophilomorphe connu de l'ambre du Mésozoïque et le deuxième représentant mésozoïque de l'ordre Geophilomorpha est décrit sous le nom Buziniphilus antiquus n. gen., n. sp. Ce chilopode est décrit à partir d'un exemplaire unique, probablement juvénile, de l'ambre du Cénomanien inférieur de La Buzinie, Champniers, département de la Charente, France. Buziniphilus n. gen. appartient très probablement à l'une ou l'autre des familles Schendylidae ou Geophilidae, mais la découverte du labre et de la mandibule demeure essentielle pour une attribution définitive à une famille. L'assignation de Buziniphilus n. gen. au "groupe-couronne" Adesmata et une réinterprétation des forcipules du genre jurassique Eogeophilus Schweigert \& Dietl, 1997, renforcent l'aspect moderne des chilopodes mésozoïques déjà mis en évidence par les fossiles crétacés appartenant aux scutigeromorphes et scolopendromorphes.

\section{INTRODUCTION}

Of the five extant chilopod orders, Geophilomorpha is the most diverse at both the familial and specific levels, its $c .1260$ described species being assigned to 14 currently recognised families (Minelli 2006). Although the fossil record of the chilopod crown-group is now known to extend back to the Upper Silurian (Shear et al. 1998), the oldest wellestablished geophilomorph fossil dates to the Upper Jurassic. Eogeophilus jurassicus Schweigert \& Dietl, 1997 , the earliest known geophilomorph, is represented by a single specimen from the Nusplinger Plattenkalk (Kimmeridgian), SW Germany. The sister group of Geophilomorpha, the Scolopendromorpha, has a first known occurrence in the Upper Carboniferous (Mundel 1979), calibrating a minimal date for divergence of these two orders, and thus predicting the geophilomorph stem-group to have been in existence by the Upper Carboniferous. Although an Upper Carboniferous taxon, Ilyodes attenuata Matthew, 1894, has been suggested as a possible geophilomorph (Shear \& Bonamo 1988), examination of the material rejects its identity as a chilopod (W. A. Shear pers. comm.).

More recent fossil geophilomorphs are represented by specimens that occur in Cenozoic ambers, notably Baltic amber (e.g., Weitschat \& Wichard
1998: pl. 22, fig. d), but this material has not received a recent systematic study. Described species from Baltic amber are limited to those named by Menge in Koch \& Berendt (1854), i.e. Geophilus brevicaudatus, G. crassicornis and G. filiformis. Another Cenozoic fossil geophilomorph, Calciphilus abboti Chamberlin, 1949, is known from a single, incomplete specimen (Chamberlin 1949). In the present work we establish a new genus and species for a geophilomorph preserved in La Buzinie amber, of Late Cretaceous age (Early Cenomanian; Perrichot et al. 2007a, b).

\section{MATERIALS AND METHODS}

A single chilopod specimen (BUZ 1.8), housed in the Muséum national d'Histoire naturelle, Paris, has been collected in La Buzinie amber (Perrichot et al. 2007a: table 2). The amber surrounding the centipede was removed with a shaving blade and the specimen was mounted in Canada balsam between cover glasses, as described by Perrichot et al. (2004). The specimen was examined under several stereo and compound transmitted light microscopes. Digital images focused at varying levels were captured using a Leica DMR microscope coupled with a Leica DFC480 digital camera. Drawings were made 
from these high magnification images. Images in Figures 1, 2 and 4 are composites of different focal planes merged in Adobe Photoshop. Descriptive terminology follows that employed in recent work on Schendylidae (e.g., Pereira et al. 2004).

\section{SYSTEMATICS}

\section{Order GEOPHILOMORPHA Pocock, 1895}

\section{Genus Buziniphilus n. gen.}

TYPE SPECIES. - Buziniphilus antiquus $\mathrm{n}$. sp.

ETymology. - For the type locality, La Buzinie, compounded with the usual geophilomorph suffix -philus.

DiAGNOSIs. - Cephalic plate slightly longer than wide. Antennae filiform, maintaining even width along entire length. Apical claw of second maxillae well developed, non-pectinate. Forcipular tergum narrower than tergum of first pedigerous segment. Forcipular coxopleural sutures evidently convergent backwards for most of their length. Forcipulae without teeth. Sternal pores absent along entire trunk. Sternum of last pedigerous segment wider than long. Last leg slightly shorter than those on preceding segments, the telopodite composed of six podomeres, without praetarsal claw.

\section{REMARKS}

In comparison to the most similar geophilomorph genera (for the criteria for selection among the extant genera, see under Discussion), Buziniphilus n. gen. differs from both Geophilus Leach, 1814, and Schendyla Bergsøe \& Meinert, 1866, in the legs of the last pair (shorter than those of preceding segments in Buziniphilus n. gen. vs. as long as or longer in both Schendyla and Geophilus) and in the coxal pores (apparently no pores in Buziniphilus n. gen., vs. at least two large pores on each coxopleuron in Schendyla and in Geophilus), from Geophilus also in the claw of the legs of the last pair (absent in Buziniphilus n. gen., vs. well developed in Geophilus); from Haploschendyla Verhoeff, 1900, and Hapleurytion Verhoeff, 1940, in the sternal pores (apparently absent in Buziniphilus n. gen., vs. present and arranged in evident pore fields in both Haploschendyla and Hapleurytion), from Hapleurytion also in the shape of the forcipular coxopleural sutures (convergent backwards for most of their length in Buziniphilus n. gen., vs. parallel for most of their length in Hapleurytion) and in the claw of the legs of the last pair (absent in Buziniphilus n. gen., vs. well developed in Hapleurytion).

\section{Buziniphilus antiquus n. sp.}

(Figs 1-4)

Chilopoda indet. - Perrichot et al. 2007a: fig. 2A.

Holotype. - BUZ 1.8 (Muséum national d'Histoire naturelle, Paris), complete specimen, probably immature.

Eтyмology. - Antiquus, with reference to the age of the species, one of two known Mesozoic geophilomorphs.

Diagnosis. - As for the genus.

Type locality. - La Buzinie amber, subunit A2 of Perrichot et al. (2007b), Champniers, département de la Charente, France; Early Cenomanian fide Perrichot et al. (2007b). Note that previous labelling of the holotype as Late Albian (Perrichot et al. 2007a: fig. 2) is an error.

\section{DESCRIPTION}

Body length c. $12 \mathrm{~mm}$; maximum body width c. $0.4 \mathrm{~mm}$ (excluding legs).

Cephalic plate only slightly domed, subrectangular, about 1.2 times as long as wide, anterior margin weakly convex or angled, lateral margins evenly convex, posterior margin weakly concave (Fig. 2A). Setae of the cephalic plate shorter than those on basal antennal articles; setae apparently sparse on dorsal surface of cephalic plate; cuticular scutes well marked on anterior and anterolateral part of cephalic plate (Fig. 2B).

Antennae well separated at their bases (Fig. 2C). Each antenna composed of 14 articles, 3.3 times as long as cephalic plate, filiform, maintaining even width along entire length, not noticeably attenuate distally (Figs 1B; 3B); setae arranged in two or three whorls on each article (Fig. 1E), much more numerous and scattered on article XIV; article XIV nearly twice as long as wide, 2.2 times as long as penultimate article XIII (Fig. 1A).

Clypeus: areolation apparently uniform, at least on central part, only a few short setae present. 

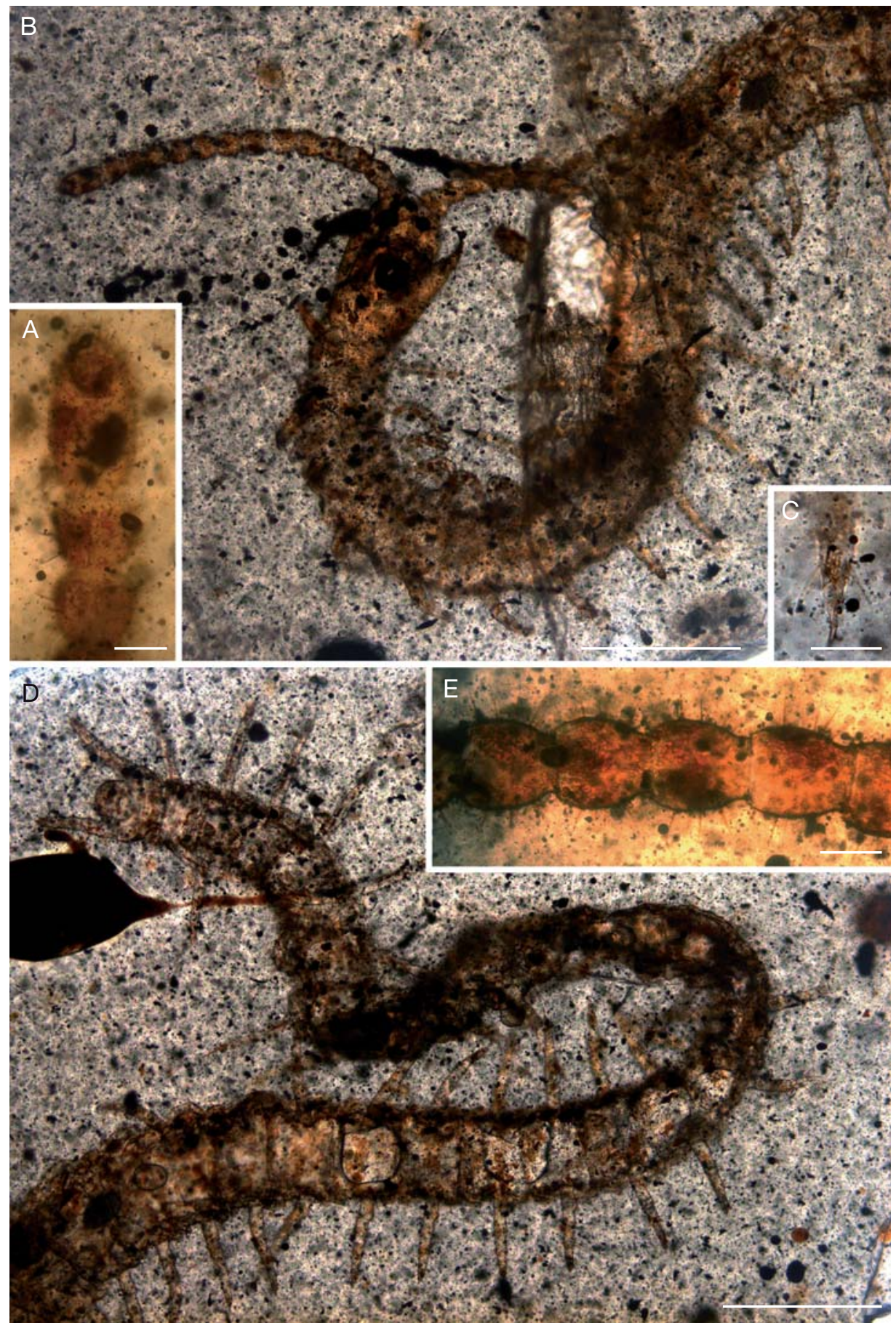

FIG. 1. - Buziniphilus antiquus n. gen., n. sp., holotype, ventral views: A, antennal articles XII-XIV, right antenna; $\mathbf{B}$, head and anterior part of trunk including pedigerous segments I-XVII; C, praetarsal claw of leg XXXVIII; D, trunk pedigerous segments XIV-XLI; E, antennal articles V-X, right antenna. Scale bars: A, C, E, $50 \mu \mathrm{m} ; \mathrm{B}, \mathrm{D}, 0.5 \mathrm{~mm}$. 

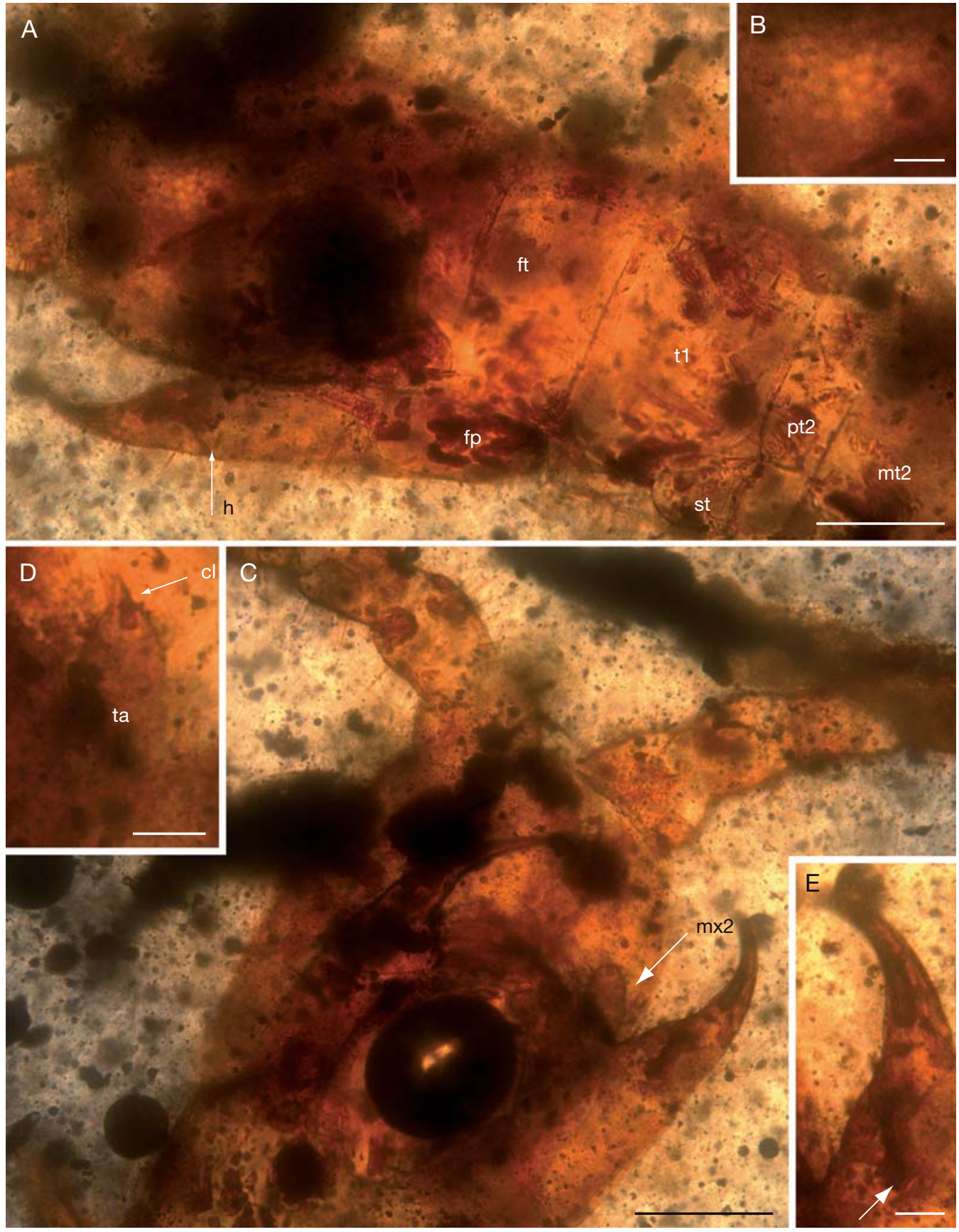

FIG. 2. - Buziniphilus antiquus n. gen., n. sp., holotype: A, dorsolateral view of head and anterior part of trunk; B, detail of scutes on anterior part of cephalic plate; $\mathbf{C}$, ventrolateral view of head; $\mathbf{D}$, tarsus and claw of left telopodite of second maxillae; $\mathbf{E}$, ventral view of distal part of left forcipula; arrow indicates distal end of poison calyx. Abbreviations: cl, claw; fp, pleurite of forcipular segment; $\mathbf{f t}$, tergum of forcipular segment; $\mathbf{h}$, hinge between trochanteropraefemur and tarsungulum of forcipula; $\mathbf{m t} \mathbf{2}$, metatergum of second pedigerous segment; $\mathbf{m \times 2}$, left telopodite of second maxillae; pt2, praetergum of second pedigerous segment; st, stigmatiferous sclerite; t1, tergum of first pedigerous segment; ta, tarsus. Scale bars: A, C, $100 \mu \mathrm{m} ; \mathrm{B}, \mathrm{D}, \mathrm{E}, 20 \mu \mathrm{m}$. 

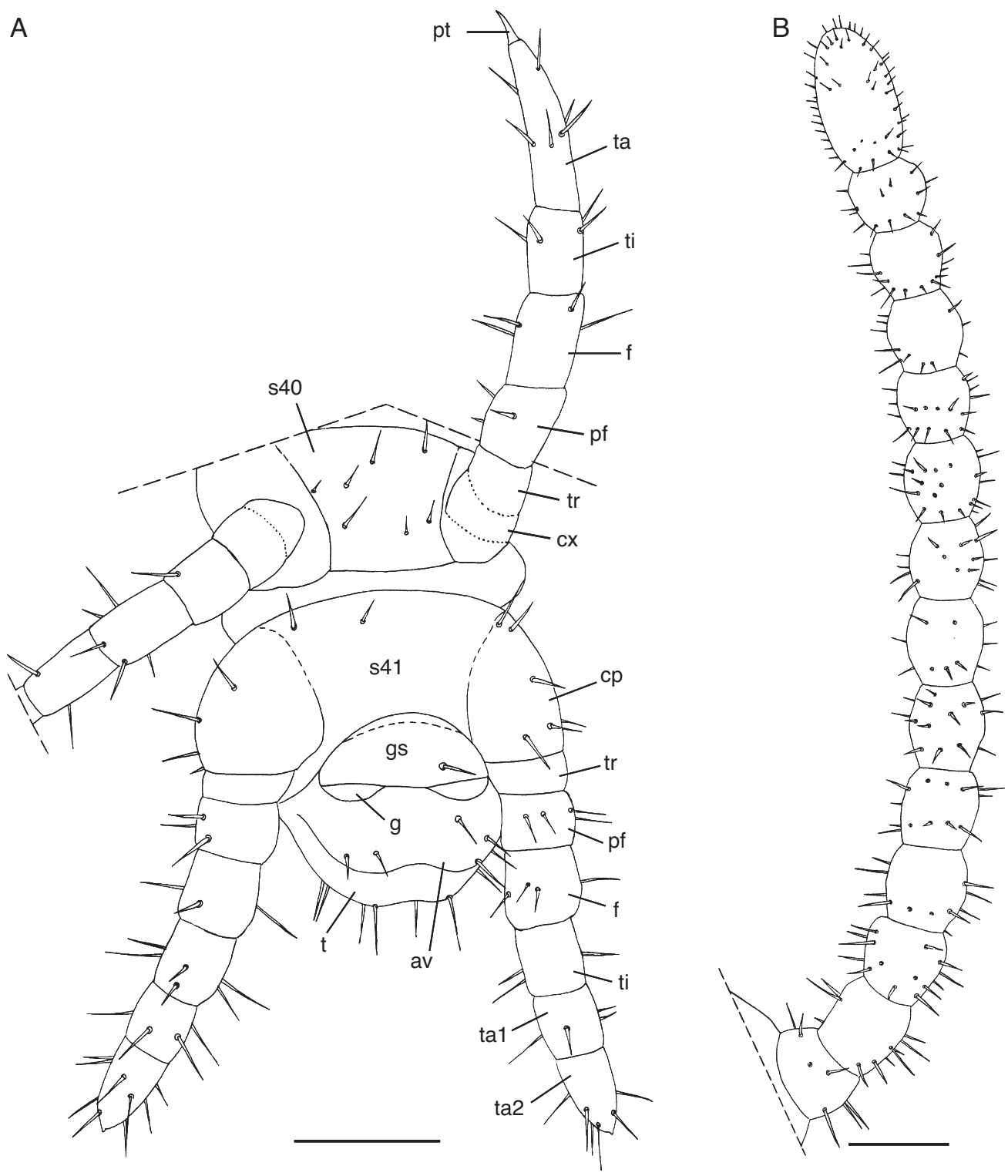

FIG. 3. - Buziniphilus antiquus n. gen., n. sp., holotype, interpretative drawings: A, pedigerous segments XL-XLI and terminal segments, ventral view (see Figure $4 \mathrm{C}$ for photograph). Dotted lines indicate expected limits of coxa and trochanter on leg XL, not visible on specimen; B, right antenna, ventral view. Abbreviations: av, anal valve; cp, coxopleuron; cx, coxa; f, femur; g, putative gonopod; gs, first genital sternite; pf, praefemur; pt, praetarsus; s40, s41, sterna of segments XL-XLI, respectively; t, telson; ta, tarsus; ta1, tarsus I; ta2, tarsus II; ti, tibia; tr, trochanter. Scale bars: $100 \mu \mathrm{m}$.

Second maxillae: apical claw of telopodite well developed, slightly curved, tapering into either a point or a flattened tip (Fig. 2D); a few robust setae at tip of tarsus near claw.
Forcipular segment: forcipular tergum narrower than tergum of first pedigerous segment so that pleurites are partially visible from above (Fig. 2A). Exposed part of coxosternum about 1.6 times as 

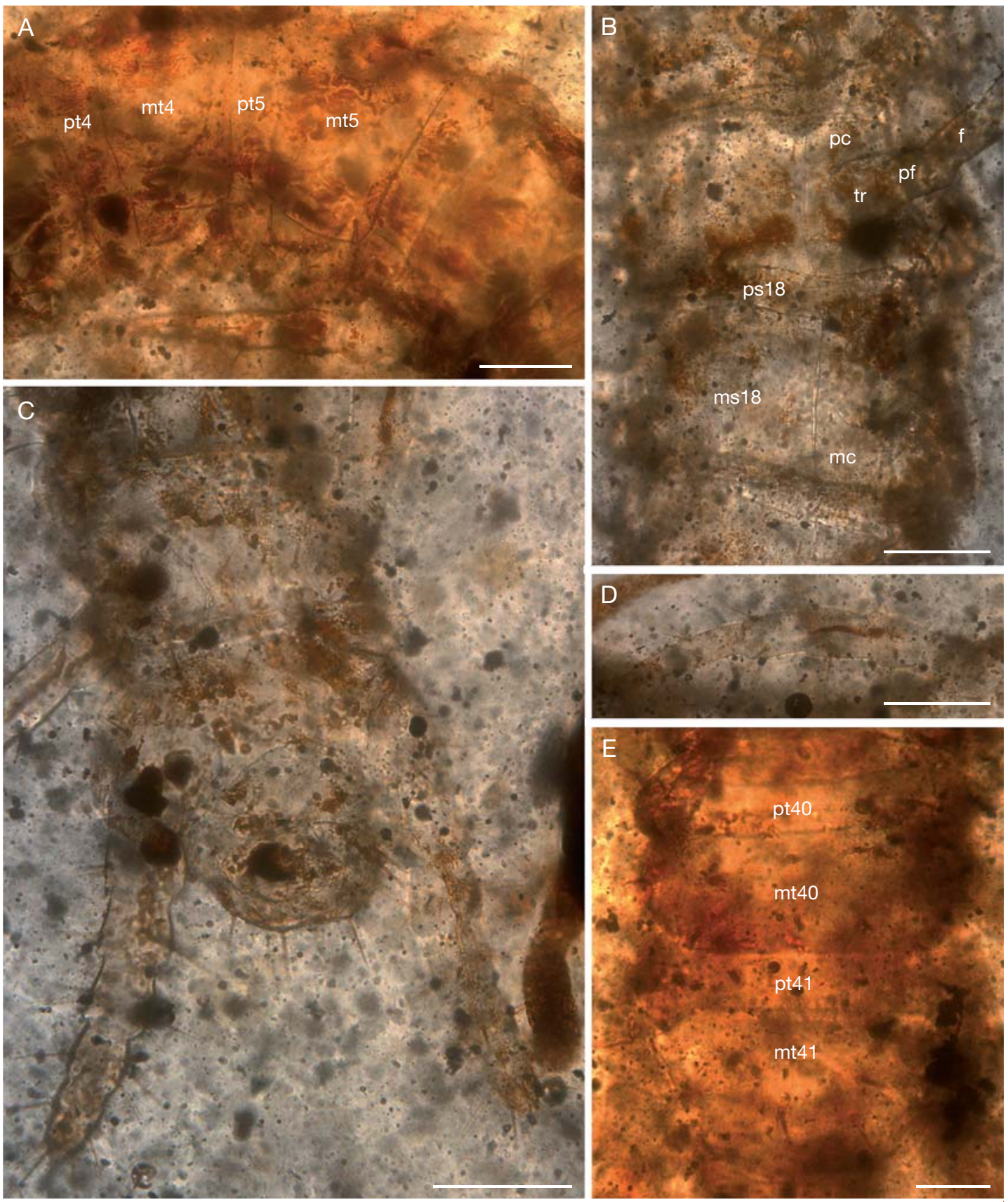

FIG. 4. - Buziniphilus antiquus n. gen., n. sp., holotype: A, dorsolateral view of pedigerous trunk segments III-VII, including leg VI; B, ventrolateral view of trunk segments XVII-XIX; C, terminal part of trunk, ventral view (see Figure 3A for labelled drawing); D, left leg XL, posterior side; E, trunk segments XL-XLI, dorsal view. Abbreviations: f, femur; mc, metacoxa; ms, metasternum; mt, metatergum; pc, procoxa; pf, praefemur; ps, praesternum; pt, praetergum; tr, trochanter. Scale bars: A-D, $100 \mu \mathrm{m} ; \mathrm{E}, 50 \mu \mathrm{m}$. 
wide as long; coxopleural sutures gently convex outwards, evidently convergent backwards for most of their length. Trochanteropraefemur about as long as wide, apparently lacking distomedial tooth. Two distinct intermediate articles, both without teeth. Hinge between trochanteropraefemur and tarsungulum along entire outer side of forcipula (Fig. 2A). Tarsungulum about 2.3 times as long as wide at base, strongly narrowing to a slender tip that is uniformly curved, non-dentate basally, with smooth inner margin. Calyx of poison gland apparently cylindrical, short, extending into femur (Fig. 2E). Closed forcipulae lying entirely behind anterior margin of cephalic plate.

Trunk with 41 pedigerous segments, marked by gradual widening of trunk to a maximum on segments XIII-XVII, then gradual narrowing posteriorly (Fig. 1B, D). Tergal setae moderately long; single row of $c$. 5 or 6 setae across praeterga; setae arranged in two rows across metaterga, including those at anterolateral and posterolateral angles (Fig. 4A). Sterna in posterior part of trunk bearing at least four main setae. Sterna without evident posterior apodemes articulating into anterior sockets (so called "carpophagus" structures), and without other kinds of sockets. Sternal pores apparently absent (Fig. 4B).

Trunk legs: telopodites, to the exclusion of those of the last pair, composed of five podomeres. First pair of legs only slightly smaller than the remaining legs. In legs I-XL, one main whorl of a few setae a short distance distal to midlength of praefemur, femur and tibia; tarsus with a setal whorl at about midlength and few setae on distal half (Fig. 3A). Praetarsal claws simple, slender, slightly curved, with tiny basal spines, uniform on legs I-XL (Fig. 1C).

Last pedigerous segment: metatergum subtrapezoidal, about 1.7 times as wide as long, about 1.2 times as long as penultimate metatergum, lateral margins rounded, posterior margin gently convex backwards (Fig. 4E). Sternum subtrapezoidal, wider than long, lateral margins convergent backwards, posterior margin evidently concave backwards (Fig. 4C); a single row of setae across its anterior quarter, apparently four in total (inferred from two setae on right half). Last leg slightly shorter and slightly thicker than those on preceding segments, the telopodite composed of six podomeres, including two tarsal articles (Figs 3A; 4C). Coxopleura only weakly swollen, coxal pores and coxal organs undetected. Podomeres with ratio of length (measured on ventromedial aspect), praefemur 0.8 , femur 1.0, tibia 0.9, tarsus I 0.9, tarsus II 1.1. Chaetotaxy of the last leg on ventral side as in Figure 3A; setae similar in length and density to those on other legs. Last legs without claws, but tarsus II apparently bearing a small, blunt tubercle.

Terminal segments: intermediate tergum with rounded posterior margin, bearing a few moderately long setae. Putative intermediate sternum possibly detectable as a very short sclerite. First genital sternum slightly more than twice as wide as long, posterior margin weakly medially convex; one seta (presumably one of a pair) on posterolateral part of sternum; no distinct pleurites detectable, i.e. sutures between sternum and pleurites apparently lacking (Fig. 3A). Putative gonopods represented by a pair of short, rounded, uniarticulate projections from posterior margin of first genital sternum, the two either separated from each other or connected medially by a very short bridge. Telson evidently swollen and longer than the first genital sternum, with pair of anal valves separated by shallow, rounded embayment; anal organs and pores undetected.

\section{DISCUSSION}

Buziniphilus n. gen. is identified as a member of the crown-group Geophilomorpha, based on the following well-established geophilomorph autapomorphies: antennae composed of 14 articles; no eyes; overall shape and structure of the forcipular segment; trunk composed of homonomous segments with strongly differentiated prae- and metaterga and prae- and metasterna; more than 23 pairs of legs. The new genus is confidently assigned to Adesmata, drawing on characters that are found among extant Adesmata but not in Placodesmata, including: forcipular coxosternum relatively short, with coxopleural sutures evidently converging backwards for most of their length; forcipulae without teeth; trunk sterna without mid-longitudinal internal apodema and corresponding external sulcus. 
TABLE 1. - Consistency of the characters of Buziniphilus $n$. gen. with the extant families of Adesmata: +, character present in family; -, character absent in family. Circumscription of families as adopted in ChiloBase (Minelli 2006). Characters: 1, shape of cephalic plate; $\mathbf{2}$, shape of antennae; $\mathbf{3}$, presence of claws on second maxillae; $\mathbf{4}$, shape of forcipular coxosternum; $\mathbf{5}$, shape of forcipular tergum; 6, shape of forcipulae; $\mathbf{7}$, general shape of trunk; $\mathbf{8}$, number of trunk segments; $\mathbf{9}$, shape of claws on anterior trunk; $\mathbf{1 0}$, absence of sternal pores; 11, number of podomeres in last pair of legs; 12, absence of claws on last pair of legs.

\begin{tabular}{lllllllllllll}
\hline & $\mathbf{1}$ & $\mathbf{2}$ & $\mathbf{3}$ & $\mathbf{4}$ & $\mathbf{5}$ & $\mathbf{6}$ & $\mathbf{7}$ & $\mathbf{8}$ & $\mathbf{9}$ & $\mathbf{1 0}$ & $\mathbf{1 1}$ & $\mathbf{1 2}$ \\
\hline Aphilodontidae & + & + & - & + & + & - & + & - & + & + & + & + \\
Ballophilidae & - & + & + & + & - & - & - & - & + & - & + & + \\
Dignathodontidae & - & + & + & - & - & - & - & + & + & + & + & + \\
Eriphantidae & - & - & + & + & $?$ & - & - & - & + & - & + & - \\
Eucratonychidae & - & - & + & - & + & - & - & - & - & - & + & + \\
Geophilidae & + & + & + & + & + & + & + & + & + & + & + & + \\
Gonibregmatidae & - & - & + & - & - & - & - & - & + & - & + & + \\
Himantariidae & - & - & + & - & - & + & - & - & + & - & + & + \\
Linotaeniidae & - & + & + & + & - & - & - & + & + & - & + & + \\
Macronicophilidae & - & + & - & + & + & - & + & + & + & - & - & - \\
Neogeophilidae & + & + & + & + & + & - & + & - & - & + & + & + \\
Oryidae & - & - & + & + & - & + & + & - & + & - & + & + \\
Schendylidae & + & + & + & + & + & + & + & + & + & + & + & + \\
Tampiyidae & + & + & + & + & - & + & + & - & + & + & + & - \\
\hline
\end{tabular}

Based on the morphological characters recognised in the fossil, Buziniphilus n. gen. is fully consistent with both Geophilidae Leach, 1814 and Schendylidae Cook, 1896, whereas it differs from all other extant families in some characters considered diagnostic at the family level (Table 1). The main characters allowing family-level classification of Buziniphilus n. gen. are: elongate, subrectangular cephalic plate; slender, filiform antennae; presence of claws on second maxillae; general shape of the forcipular segment, including shape of the coxosternum, extension of the tergum, structure of forcipulae and absence of forcipular teeth; shape of claws of the legs; structure of the last pair of legs and absence of claws on that leg pair. It is impossible to classify Buziniphilus n. gen. in one of either Geophilidae or Schendylidae with confidence because we lack information on the most highly diagnostic characters distinguishing between those two families, the shape of the labrum and structure of the mandibles. In the extant biota, these families are the two most diverse families in Adesmata (c. 560 species in 113 genera of Geophilidae, c. 220 species in 33 genera of Schendylidae; cf. Minelli 2006) and both are well represented in the Palaearctic region. Taking into account all characters recognised in Buziniphilus n. gen. (including the relatively low number of segments, as well as the apparent absence of sternal pores), Buziniphilus n. gen. resembles both some extant species of Palaearctic Schendylidae (e.g., some species of Schendyla) and some extant species of Palaearctic Geophilidae (e.g., some species of Geophilus).

As for the coxal and sternal pores, which are also widely employed in geophilomorph taxonomy, we infer with moderate confidence that the lack of pores in the appropriate positions in the fossil is due to real absence rather than merely nonvisibility in the specimen. In both Schendylidae and Geophilidae, the two extant families to which Buziniphilus n. gen. most closely compares, some genera lack sternal pores (summarised in Turcato et al. 1995), whereas very few (e.g., Hapleurytion and Haploschendyla) lack coxal pores, though the latter are frequently more or less concealed under the sternum or may open into pouches ("adenocrypts"). Apart from some intrinsic limb musculature and the cuticularised forcipular poison calyx, internal anatomy of the fossil specimen has been lost to decay and accordingly we view the absence of coxal organs and sternal glands as less meaningful than the lack of the corresponding pores at which those organs and glands open. 
The observed characters do not allow a decisive assessment as to whether or not the holotype of Buziniphilus antiquus n. gen., n. sp. is fully developed, but some evidence suggest that it is likely a juvenile. Most notable is the relative size of structures at the posterior end of the body: the coxopleura are only weakly swollen, the last legs are relatively short, and the terminal segments are relatively large. In extant geophilomorphs, these proportions are more usual in juvenile than in adult specimens. Paired structures that we identify as gonopods (Fig. 3A) are relatively short and do not cover the relatively large anal valves. Although such small gonopods resemble juvenile morphology, it must be noted that adult females of Geophilidae may have similar proportions. The apparent absence of coxal pores (or their sparseness or concealment by the sternum, if indeed present) is also comparable to juveniles.

The sex of the specimen is rather more doubtful than its developmental stage because most reliable sex-diagnostic characters are unknown or ambiguous, in particular the uncertain structure of the putative gonopods. We regard it as more likely that the specimen is female, considering that no pleurites are distinct from the first genital sternum, i.e. no sutures are detected between the sternum and pleurites, a character that is diagnostic of geophilomorph females.

\section{CONCLUSIONS}

The Late Cretaceous Buziniphilus antiquus n. gen., n. sp. is in high probability a member of an extant family, either Schendylidae or Geophilidae, reinforcing the view that Mesozoic chilopods are deeply nested in crown-group clades (Wilson 2001, 2003). In other orders, the Lower Cretaceous scutigeromorph Fulmenocursor tenax Wilson, 2001 is apparently referable to the extant family Scutigeridae Leach, 1814, based on the shape of its antennal articles (wider than long, as in Scutigeridae and Scutigerinidae Attems, 1926), pair of spine bristles on the tibia of the second maxillae (shared by Scutigeridae and Pselliodidae Chamberlin, 1955), and apparently styliform (male?) gonopods (autapomorphic for Scutigeridae). Likewise the coeval scolopendromorph Cratoraricrus oberlii Wilson, 2003 possesses some characters typical of an extant family, Scolopendridae Leach 1814, such as bipartite tarsi and complete paramedian grooves on the sterna. Indeed, the latter character suggests a more precise comparison to the tribes Asanadini Verhoeff, 1907 and Scolopendrini Leach, 1814.

A possible exception to this pattern of membership of Mesozoic chilopods in extant families would be forced by a peculiar construction of the forcipula putatively documented in the Jurassic geophilomorph Eogeophilus jurassicus Schweigert \& Dietl, 1997. Eogeophilus Schweigert \& Dietl, 1997 was depicted as having a complete femur and tibia on the forcipula (Schweigert \& Dietl 1997: fig. 4), whereas extant geophilomorphs share a joint between the first and fourth articles of the telopodite (the trochanteropraefemur and tarsungulum), completely reducing the second and third articles (femur and tibia) on the outer side of the telopodite. A hinge between the trochanteropraefemur and tarsungulum is also observed in Buziniphilus antiquus n. gen., n. sp. (Fig. 2A). The fact that this modification is shared with scolopendromorphs has led to the reduced articles being regarded as a synapomorphy for Scolopendromorpha and Geophilomorpha, i.e. autapomorphic for the clade Epimorpha (Attems 1929; Dohle 1985). If Eogeophilus were correctly interpreted, this taxon would be a stem-group geophilomorph and convergence is forced between scolopendromorphs and crown-group geophilomorphs. We regard it as more likely that the single specimen of $E$. jurassicus can be reinterpreted as showing the typical Epimorpha hinge. The lines depicted as the articulation between the trochanteropraefemur and femur in figure 4 of Schweigert \& Dietl (1997) instead actually appear to be the articulation between the coxosternum and the base of the telopodite (i.e. the base of the trochanteropraefemur). This interpretation would result in the specimen having more typical geophilomorph proportions of the coxosternum and telopodite, and eliminates the need to posit homoplasy between the hinged forcipulae of geophilomorphs and scolopendromorphs.

\section{Acknowledgements}

This study was made possible by the loan of the valuable specimen by Vincent Perrichot, who also 
skillfully prepared it for examination. Research on Cretaceous ambers is supported by the Agence nationale de la Recherche (ANR) project AMBRACE no. BLAN07-1-184190. W. Shear provided information on Ilyodes. We thank G. Giribet and an anonymous referee for comments on the manuscript.

\section{REFERENCES}

ATtems C. 1929. - Myriapoda 1. Geophilomorpha, in Schulze F. E. \& KÜKENTHAL W. (eds), Das Tierreich, 52. Walter de Gruyter, Berlin, 388 p.

Chamberlin R. V. 1949. - A new fossil centipede from the Late Cretaceous. Transactions of the San Diego Society of Natural History 11: 117-120.

DoHLE W. 1985. - Phylogenetic pathways in the Chilopoda. Bijdragen tot de Dierkunde 55: 55-66.

KoCH C. L. \& BERENDT G. C. 1854. — Die im Bernstein befindlichen Crustaceen, Myriapoden, Arachniden und Apteren der Vorwelt, in BERENDT G. C. (ed.), Die im Bernstein befindlichen organischen Reste der Vorwelt. Nicolaischen Buchhandlung, Berlin, 124 p.

Minelli A. (ed.) 2006. - ChiloBase. A World Catalogue of Centipedes (Chilopoda) for the Web. Available online at: http://chilobase.bio.unipd.it (last accessed the 9th February 2009).

Mundel P. 1979. - The centipedes (Chilopoda) of the Mazon Creek, in NiTECKI M. H. (ed.), Mazon Creek Fossils. Academic Press, New York: 361-378.

Pereira L. A., Minelli A. \& Uliana M. 2004. The species of Schendylops Cook, 1899 (Chilopoda, Geophilomorpha, Schendylidae) from Madagascar. Zoosystema 26 (4): 727-752.

Perrichot V., Nel A. \& Néraudeau D. 2004. - A new, enigmatic, evaniomorphan wasp in the Albian amber of France (Insecta: Hymenoptera). Journal of Systematic Palaeontology 2: 159-162.

Perrichot V., Nel A. \& Néraudeau D. 2007a. Schizopterid bugs (Insecta: Heteroptera) in MidCretaceous ambers from France and Myanmar (Burma). Palaeontology 50: 1367-1374.

Perrichot V., Néraudeau D., Nel A. \& De Ploëg G. 2007b. - A reassessment of the Cretaceous amber deposits from France and their palaeontological significance. African Invertebrates 48: 213-227.

SChWEigert V. G. \& Dietl G. 1997. — Ein fossiler Hundertfüssler (Chilopoda, Geophilida) aus dem Nusplinger Plattenkalk (Oberjura, Südwestdeutschland). Stuttgarter Beiträge für Naturkunde B (Geologie und Paläontologie) 254: 1-11.

Shear W. A. \& Bonamo P. M. 1988. - Devonobiomorpha, a new order of centipeds (Chilopoda) from the Middle Devonian of Gilboa, New York State, USA, and the phylogeny of centiped orders. American Museum Novitates 2917: 1-30.

Shear W. A., Jeram A. J. \& Selden P. A. 1998. - Centiped legs (Arthropoda, Chilopoda, Scutigeromorpha) from the Silurian and Devonian of Britain and the Devonian of North America. American Museum Novitates 3231: 1-16.

TurCATO A., FusCo G. \& Minelli A. 1995. - The sternal pore areas of geophilomorph centipedes (Chilopoda Geophilomorpha). Zoological Journal of the Linnean Society 115: 185-209.

Weitschat W. \& Wichard W. 1998. - Atlas der Pflanzen und Tiere im Baltischen Bernstein. Verlag Dr Friedrich Pfeil, Munich, 256 p.

Wilson H. M. 2001. — First Mesozoic scutigeromorph centipede, from the Lower Cretaceous of Brazil. Palaeontology 44: 489-495.

WiLSON H. M. 2003. - A new scolopendromorph centipede (Myriapoda: Chilopoda) from the Lower Cretaceous (Aptian) of Brazil. Journal of Paleontology 77: 73-77.

Submitted on 4 October 2007; accepted on 25 January 2008. 